\title{
Returning 'learning' to education: Toward an ecological conception of learning and teaching
}

\author{
Cary Campbell \\ Faculty of Education \\ Simon Fraser University \\ Burnaby, British Columbia \\ Canada \\ e-mail: cary_campbell@sfu.ca
}

\begin{abstract}
This article describes a notion of learning as adaptive semiotic-growth. In line with the theme of this special issue, learning will be approached on a broad ecological and evolutionary continuum - most generally expressed as a form of adaptation to the environment. Viewing learning through the criterion of signification (semiosis) means that learning is continuous across the entire biological realm. Both the life process and the learning process are expressed through forms of semiotic-engagement and involve continual adaptation and meaning-making. Thus, learning cannot be seen as unique to humans. Learning is more broadly ecological before it is "cultural". From here we can imagine educational institutions as forms of exaptation, that evolved naturally to channel learning more effectively. Thinking of learning on an ecological continuum means that learning cannot be "located" or pinned down easily in educational research or practice. Rather, learning has a sporadic identity; it is emergent in the specificity of events and must be discerned within the practices that enact it. Realizing learning as something emergently enacted in the educative encounter, and not something that can be determined and implemented, allows us to resist turning learning into an accountability tool that can easily be used towards ideological ends.
\end{abstract}

Keywords: learning; adaptation; edusemiotics; biosemiotics; modelling; teaching; pedagogy 
The difference between anything meaningful and anything that has no meaning can be described as a difference between the unique and the plural, or one and many.

Kalevi Kull ${ }^{1}$

\section{To go on learning}

It is difficult not to consider life as a process of becoming plural. Plurality, after all, is the essence of growth and becoming. To become implies becoming something other than oneself - not a new entity altogether, but a growing into the other.

From my earliest struggles with the mechanics of reading and maths, unable to focus on the symbols on the page or in my mind, I came to think of myself as a learner. Someone capable of undergoing transformative growth, someone capable of constantly adapting and varying their interactions and responses to the environment. I came to this understanding because I recognized a potential in myself. This was a belief that I did not need to take on authority, and in fact seemed to be counteracted and rejected by most of my teachers. Still, it was a belief that I intuitively knew and would continue to adapt to my changing experience. Thinking back, this "learning" I underwent was never the result of acquiring new information, or data, nor the result of acquiring problem-solving strategies. No rather, it was a process of realizing plurality through achieving presence.

I knew that many of my struggles with dyslexia could be overcome if I could achieve some sort of presence of mind and body. I learned that if I could enter into the evolving grain of things - find a groove and hang on, so to speak, then I would be capable of spelling things correctly, reading (music or text) properly,

1 Morten Tønnessen interviewing Kull: "M [Interviewer]: What kind of plurality are we talking about? K[ull]: The difference between anything meaningful and anything that has no meaning can be described as a difference between the unique and the plural, or one and many. Everything that has meaning is plural. M: So what is unique or unitary, what is only one, cannot be meaningful, because being meaningful implies multiplying of what is meaningful. $\mathrm{K}$ : The problem is that it is almost impossible - or at least quite hard - to imagine something that completely lacks meaning. On the other hand - this is exactly what physics has to do. M: A non-semiotic approach would treat an object of biology as one objectified object only, and not as a plurality, and would thus lose a lot of the meaning involved...” (Magnus, Tønnessen 2010: 7). See also Alin Olteanu (in Stables et al. 2018: 117): “That plurality is the basic and necessary condition for learning [...] implies the need for cultivating and enhancing plurality. Biological evolution provides clear examples of this enhancement, arguably driven by the rationale of learning. As explained, biological phenomena are driven semiosically, semiosis being the principle of pluralistic development itself." 
etc. My dyslexia would become manageable and perhaps even assist me creatively in the educative process. It would not matter how many times a math teacher yelled at me in frustration (and I am sad to admit it happened frequently) to "just remember the formula!" If I failed to experience this "coming into presence" as I performed these computations, then I would have no hope of comprehension, and even less of retention. Through these failures and tribulations, I learned that to learn (or perhaps more accurately, to go on learning something) was to experience a simultaneous event of doing-undergoing; to have what you do in an environment lead into what you undergo in a continuous process. If doing did not anticipate undergoing in a finely tuned, self-referential feedback loop, then I would be out of the running before I even began. But, if I gave myself sufficient time and space, I could often find ways to enter into events. I would be able to "cleave the event from within" (Ingold 2017: 42), and through this freedom from being-in-habit, be able to follow down the words on the page; my dyslexia somehow, to my own surprise, remedying itself before me.

Unfortunately, this was not the way I was taught by most of my teachers. Us students were mostly taught to perform drills, under the pressure of time. This was very important. We were often didactically "taught", before experiencing things for ourselves, context-independent "rules of encoding and decoding", from which we would deduce necessary answers.

As you can imagine, this sort of approach to teaching does not work well for a dyslexic child. More importantly however, all of us who have ever experienced these sorts of educational practices, experience our world being divided into heavy dualities: mind/world, subject/object, culture/nature, content/expression, event/description, signifier/signified. The consequence of these educational and more specifically pedagogical - failures, I argue, arises from a fundamental misunderstanding about what learning is and its role in educational dynamics and organizations. This is often displayed in the way society collectively explains the role, purpose (telos), and results of the educational process.

For this special issue of Sign Systems Studies, I will describe a notion of learning as adaptive semiotic-growth. I have advanced various dimensions of this 'learning theory' elsewhere and I will be referring to these other articles throughout. In line with the theme of this special issue, I argue that learning can be approached on a broader ecological continuum - most generally expressed as a form of adaptation to the environment. Viewing learning through the criterion of signification (semiosis) means that learning is continuous across the entire biological realm. Both the life process and the learning process are expressed through forms of semiotic-engagement and involve continual adaptation and meaning-making. Thus, learning cannot be seen as unique to humans. Learning is more broadly 
ecological before it is "cultural". From here we can imagine educational institutions as forms of exaptation, that evolved naturally to channel learning more effectively. Thinking of learning on an ecological continuum means that learning cannot be "located" or pinned down easily in theory or educational practice. Rather, learning has a sporadic identity; it is emergent in the specificity of events and must be recognized within the contexts and practices that enact it. The 'educative event' I speak of, is expressed in a coming into presence with others, articulated by the emergence of previously unactualized possibilities for action and perception in a constantly evolving environment. ${ }^{2}$ This acknowledgement of learning as a sporadic form of continual becoming (cf. Stables 2012) ensures that we recognize the limits of determinist accounts in describing and observing learning. Realizing learning as emergent and sporadic, and not something that can be determined and implemented, allows us to resist turning learning into an accountability tool that can easily be used towards ideological ends.

Learning, as I present it here, is: (1) rooted in processes of doing and making with others in a shared environment, ${ }^{3}$ and; (2) part of a larger (cosmic) process of semiotic evolution (the growth of meaning in its broadest consideration). This article is in a sense a re-imagining of learning outside of the domain of formal education, on multiple levels:

(A) In respect to the term's common interpretations in educational and everyday discourses, as the attribution of significance to certain forms of change (Sections 2 and 3).

Then,

(B) explored as a general biological attribute, co-extensive with the life process, but not strictly equivalent to it (Section 4);

And, finally,

(C) expressed in the growth and evolution of signification (semiosis), connected to the way organisms come to know (or "model") their environment - and, on a wider level, connected to the "generalizing tendency" of the universe itself, how the universe comes to know itself (Section 5).

2 I will show that, from a perspective rooted in Peirce's semiotic philosophy of perception, the 'event of learning' (Section 4) emerges from a rupture in the continuity of habitual engagement with an environment (umwelt). This is the site of new semiotic possibilities, new habit-taking, new ways of relating to the environment.

3 Or what anthropologists often call processes of enskillment, cf. Ingold 2000 and Wattchow, Prins 2018. 
Through this gradual procedure of telescoping various understandings of learning, ${ }^{4}$ I hope to, as Olteanu says, explore the possibilities for "liberating the concept of learning from the domain of education, and rethinking education as a system or a program that works in the service of learning" (Olteanu, Campbell 2017). ${ }^{5}$

Through this inquiry, I will try to explain how learning is central to living a life that is meaningful. I will show that this basic alignment (learning with living) rests in a notion that both living and learning are continuous and embedded in related processes of growth and self-referentiality. This implies that humans and animals alike only know the mind-independent "things" of their environment through attributing meaning to them: by re-cognizing them as "signs" within their species specific phenomenal world (or umwelt). ${ }^{6}$ As we will be seeing, this requires conceptualizations that think of mind and matter as continuous (synechism) and related - not as distinct entities. From this perspective, semiosis (the growth of signification) is what mediates the learner to the world, and semiosis transcends any nature/culture, matter/mind dichotomies.

\section{Controlling 'learning'}

Sadly, learning in our society has largely become concerned with the achievement of good outcomes. Of course, 'good' is always a metamorphizing compendium of societal opinion and activity. At certain times in history, 'good learning outcomes' has meant and necessitated a transactional model of education which required 'obedience and passivity to the teacher as a conveyor of knowledge'. In the modern corporate university, good outcomes are now generally concerned with making

\footnotetext{
4 An analogy for which I am indebted to Michael Ling (Simon Fraser University).

5 Olteanu, Alin; Campbell, Cary 2017. An interview with Alin Olteanu: Learning, signs, and the history of ideas. In: Benkaiouche, Marion (ed.), Philosophasters.org/interviews.

https://philosophasters.org/blog/2017/11/8/an-interview-with-alin-olteanueducationsignsand-the-history-of-ideas (accessed 27 February 2018).

This is not at all a rejection of formal education outright. But rather, as Michael Ling (personal correspondence) says, an "uncoupling" of "learning' from 'schooling', so we can see more clearly what learning looks like in terms of human flourishing, both individually, and collectively".

6 This has been called the "Continuity Principle" which rests on Peirce's doctrine of synechism. In my recent article "Educating semiosis: Foundational concepts for an ecological edusemiotic" (Campbell 2018d) I outline four basic principles that Peircean edusemiotic conceptualizations can be said to rest upon. These are: (1) the iconicity hypothesis (IH); (2) the natural learning flow principle (NLFP); (3) the continuity principle (CP); (4) the principle of suprasubjective relation (PSR). In this article I will be mainly discussing the CP and PSR, with some reference to the IH.
} 
things easily consumable to the student. Italian cultural theorist Franco "Bifo" Berardi argues that this is one of the most pernicious and ubiquitous expressions of power in this "neo-liberal" historical moment: power, he says, referencing the words and ideas of Bill Gates, resides in "making things easy" (Berardi 2012: 15).

One consequence of our modern consumer models of education is demonstrated within the social phenomenon of e-learning. In e-learning culture, excessive strain is put on facilitating learning. Learning has to be available when the student wants it, at any time, and more than this, be palpable and enjoyable on the student's terms and conditions.

It is notable that e-learning is now the dominant coinage, and not e-education. The rise in 'e-learning' culture, and its largely unquestioned acceptance in schools and universities, can be better understood through a lens of what the educational philosopher Gert Biesta labels, with a deliberately ugly term, learnification. Learnification refers to the effects of the prevalent language and 'discourse of learning' that has dominated educational discussions for around two decades. These effects are evident in several educational trends of the past two decades: the attribution of the 'learner' identity to all (even those not currently undergoing educational programs); the widespread change from "life-long education" to "lifelong learning"; and the rise in simplistic constructivist theories of learning, that undermine pedagogy and teaching.

The English word 'learning' has two obvious distinguishing attributes: aside from being a process term, it is an individuating term. As just mentioned, the individualizing aspect of the language of learning has "shifted attention away from the importance of relationships in educational processes" (Biesta 2016[2013]: 63). Very easily, as Biesta points out, learning becomes a tool of neoliberal policy. Political problems quickly become "learning problems" (Biesta 2016[2013]: 67) and individuals are responsible for being 'lifelong learners', which in this narrow context basically means that they are "responsible for keeping up their employability in rapidly changing global markets" (Biesta 2016[2013]: 67). He continues: "[T]he issue is entirely defined as a question of individual adaptation and adjustment - as a matter of learning - and not as one about structural issues and collective responsibilities" (Biesta 2016[2013]: 67).

This discourse has major existential consequences for the very practice of education, according to Biesta (2013: 36):

The quickest way to express what is at stake here is to say that the point of education is never that children or students learn, but that they learn something, that they learn this for particular purposes, and that they learn this from someone. The problem with the language of learning and with the wider 'learnification' (Biesta, 2010a) 
of educational discourse is that it makes it far more difficult, if not impossible, to ask the crucial educational questions about content, purpose and relationships. ${ }^{7}$

This culturally mandated learner identity in one quick swipe undermines that important '-ing' function. The fact that learning is a process. This process aspect of the term is important for our societal conceptions of the role of education. As Biesta (2016[2013]) has outlined in The Beautiful Risk of Education, education is ambiguous, fundamentally unpredictable, radically open (cf. Campbell 2018b), and existentially weak. While disagreeing with some aspects of Biesta's critique on learning, I agree that the reduction of learning to something individualized and controllable (as displayed in most e-learning) runs antithetical to the (semiotic) understanding that learning is expressed in the growth of signification. Effectively, learnification makes exploring qualitative educational dynamics irrelevant, and has the unwanted effect of "naturalizing" the concept, presenting learning as something everyone implicitly does, without explaining why or how. ${ }^{8}$

7 Learnification, as expressed in much 'e-learning' that happens these days, is a market-driven expression of a far more prevalent cultural conviction; that learning should be operationalized in the service of society. The trend towards increasing standardization in the North American educational context has only grown since the 1980s and shows little evidence of slowing down. Doug Ford's new conservative government in Ontario (Canada) is a depressingly topical testament to this. In just a few short weeks he has scrapped the newly reformed Sex Ed curriculum, reverting it to its 1998 iteration, promising along with these changes the creation of a website (or "snitch line") from which students and parents can report "problem" teachers who refuse to teach this newly reverted curriculum. Immediately following his election win, Ford promised a "back-to-basics" approach for his government's reform of the province's public education. As we have seen over and over again in the past, generally these pronouncements imply greater standardized measures (for students, teachers, and administrators) as well as less funding for arts education in particular. See, for journalistic response to Doug Ford's educational reforms: https://www.theglobeandmail.com/opinion/article-doug-ford-is-failingon-the-education-file/; and, for response to the Ford "snitch line", https://www.theloop.ca/ teachers-arent-happy-about-doug-fords-new-sex-ed-snitch-line/.

8 This is not an argument between left- or right-wing political agendas, but rather, as we will particularly see in section 5 , between top-down and bottom-up conceptualizations. Both the left and the right wish to improve their model of what 'good learning is' whenever they gain public office. The issue is the ideological cult of solutions, productivity, and accountability itself that destroys an appreciation of learning and teaching as emergent and sporadically enacted. Whatever the idea of progress happens to be, this operationalizing of learning in curriculum, policy and its various forms of expression, means learning can always run the risk of being reduced to an accountability tool. This is perhaps one of the ways in which Western democracies have largely, without necessarily intending to, robbed the majority of formal educational programmes of their truly 'educative' qualities. 
Because of the essential indeterminacy of education dynamics, I believe semiotics provides an ideal vocabulary and syntax, as it is inherently a metascience embracing and describing processes of mediation (i.e. signs). As Peirce says, semiotics is the "logic of vagueness" (cf. Chiasson $2002^{9}$ ). From this basic understanding, I will try to show how the 'event of learning' is always sporadic; enacted in the growth of meaningful relationships with the environment. Learning, in this estimation, is not some sort of naturalizing force, but is always emergent, singular, local and occasional. From a pedagogical perspective, learning is, like the very practice of democracy according to Rancière (1999: 33), "a mere assumption that needs to be discerned within the practices implementing it". It is according to this logic of vagueness, I argue, that we may embrace this defining indeterminacy of teaching and learning.

I will also aim to show that understanding learning as the growth of signification means that learning can never be pinned down or operationalized. And in this sense, it is not something that education is required to put into service:

The institution of education is about channeling learning rather than developing it. Thus, engagement in practices is all-important [...] if teachers claim they are teaching students to learn in general, they are unwittingly exaggerating, for they are rather engaging students in activities that are designed to result in their being deemed to have learnt specific things. (Stables et al. 2018: 18)

It is through this understanding of learning and its relation to education and teaching, that we can appreciate Maxine Greene’s (2001[1972]: 15) reflection, when she asks with Heidegger,

Why is teaching more difficult than learning:

Not because the teacher must have a larger store of information, and have it always ready.

Teaching is more difficult than learning because what teaching calls for is this: to let learn.

The real teacher, in fact, lets nothing else be learning than - learning. His conduct, therefore, often produces the impression that we properly learn nothing from him, if by "learning" we now suddenly understand the procurement of information.

The educator teaches students not curricular "knowledge-objects", but rather, ways to be in relationship with things (see Campbell 2017: 18), so that the learner

9 Chiasson, Phyllis 2002, "Peirce's logic of vagueness" was accessed online at http://www. digitalpeirce.org. 
may continually find new meaning. When learning equals the achievement of standardized "good outcomes", learning becomes a simple means-ends mechanism. Teachers, within such a model, are construed as "instruments of the state", actualizing and transferring a standardized curriculum onto passive students - as the above-mentioned Ford "snitch line" (Footnote 9) is testament to. It is almost needless to say (yet I shall say it anyway) that such a reduction (learning $=$ good educational outcomes) reifies learning from its experiential basis. And the feeling and significance that we attribute and demarcate through this concept of learning has little connection to what is emphasized and enacted through formal education.

\section{Differing senses of education}

Of course, the concept of learning we have will be deeply connected to our underlying conception of education. There are two main Latin origins to the concept of 'education' itself, and both suggest different notions of what learning is. 'Educare' means to train or to mould, while 'educere' implies a process of leading, or drawing, out. Bass and Good (2004: 162) explain further:

[T] here is an etymological basis for many of the vociferous debates about education today. The opposing sides often use the same word to denote two very different concepts. One side uses education to mean the preservation and passing down of knowledge and the shaping of youths in the image of their parents [educare]. The other side sees education as preparing a new generation for the changes that are to come - readying them to create solutions to problems yet unknown [educere]... To further complicate matters, some groups expect schooling to fulfill both functions, but allow only those activities promoting educare to be used.

'Educare' implies a logic of control, of passing down what is valued from a culture. On the other hand, 'educere' seems to imply an experiential transformation, where what has been passed down through social learning can be reborn, and reinterpreted by the new generation - so the infinite flow of signification may continue, advancing the adaptive capabilities of the social group. Additionally, the purpose or telos of educere implies growth and shared experience; not a shallow conception of individualized adaptation (bootstraps mentality), but a collective (arguably ecological) response to uncertainty, novelty, and ambiguity.

Reflecting on a 40-plus-year career as an educator and anthropologist, Tim Ingold has recently explored the experiential aspects of this notion of educere in his book Anthropology and/as Education (2017). He explains his perspective in interview (Ergül, Ingold 2017: 8): 
Education, for me, is about what it means not just to live life but to lead it. The word comes from the Latin compound ex (out) plus ducere (to lead). Thus, to educate is literally to 'lead out'. This is the very opposite of what it is commonly taken to mean today, namely to instil, into the minds of novices, the approved knowledge, values and mores of a society. Education in this majoritarian sense starts from the assumption that the novice is ignorant, therefore weak and vulnerable. To make our way in society, it is supposed, we need to be provided with the intellectual armoury to cope with the vagaries of experience, and the combative skills to hold our positions and defend them. Knowledge gives us strength and power. But it does not always make us wise. For the more we think we know, the less inclined we are to attend to what is there, to listen to other people and things around us, and to learn from them. Wisdom lies in not pretending that we already know, or that problems already contain their solutions. In the minoritarian sense of leading out, education is a process of becoming wise to things, and to the world. It teaches us to attend, and to learn from what we observe. Far from making us strong and invulnerable, this kind of education disarms us: it leaves us feeling exposed, literally 'out of position'. But it also allows us to open up to the truth of what is there. ${ }^{10}$

Ingold has written and taught widely on how embodied processes of enskillment - learning to hunt-fish-forage, weave or sing, making (Ingold 2013) art and craft alike - fundamentally form the ways in which we humans perceive, understand, and 'dwell' in the world (see Ingold's classic text The Perception of the Environment, 2000). No doubt, all social learning requires both dimensions of education, educere and educare, and this interplay of 'transmitting knowledge' and 'drawing out' suggests almost metaphorically how learning and teaching are oriented around shared practices, and thus necessarily interdependent. However, for Ingold, the experiential aspects of educative encounters are expressed in significant transformation and shared discovery which suggests the movement of educere - or more properly ex-ducere (Masschelein 2010). This is feeling of defamiliarization, of being led out of our familiar positions and habits so that we may re-cognize the world anew.

As noted by a fellow anthropologist-turned-educationalist Michael Ling (personal correspondence), when students reflect back to their significant educative experiences, they often express a sense of transformation that they have been able to make meaning from, in the sense that it "maps" onto their previous knowledge and experience. He shares the following anecdote in relation to distinctions of informal and formal educational settings:

10 See also my interview with Ingold: https://philosophasters.org/blog/2018/4/15/timingold-on-improv-writing-and-the-future-of-education. 
In my undergrad course, one of the first in-class activities I ask them to do is identify and describe what their best and worst school experiences have been, AND, an example of where and what they have learned most in "formal" (i.e. school) settings, and where and what they have learned best in an "informal" setting (i.e., in the wider Lebenswelt that informs their umwelt). Time and again, the significant learning in "school" settings has to do with when they were able to actually chart out the learning trajectory themselves, and, time and time again, there is more significant learning in "informal" settings than in formal ones - if I was of a certain cast of mind, I suppose I could do a "study" on that but for the moment, that informal "statistic" is enough for me. (Ling, personal correspondence)

Stables, in the recent co-authored volume Semiotic Theory of Learning, presents a similar understanding of learning as "the recognition and attribution of significant change":

Learning is not, strictly, something we do, but something, it is deemed we have done as a result of certain actions and outcomes; while all of living is about signification, on a semiotic account, learning is about that which has become to be regarded as particularly significant in the context of a person's life trajectory. (Stables et al. 2018: 18)

In other words, for a semiotic account of educational practice things are-whatthey-mean, and learning is located, not in the "mental state of the learner", but in the habits of relationship they form with the world. Thus, I believe that our notion of learning we use as scholars must always be consistent to some degree with how the term functions in common usage. In this sense there can be "no observational test of learning, as learning is always revealed as a qualitative version of change, and change is ubiquitous" (Stables 2016: 44).

It is when we ask such basic and fundamental questions about the "meaning of learning" in everyday life that we realize that this event or process we label learning, is always being perpetually deferred into time, and never seeming to "occur" at all. When we say things like "I've learned something" or "I think I'll learn from that experience" we are really using the concept of learning as an attribution of significance that we either anticipate or project retrospectively. This is in itself an important example of how a basic tenet of semiotics - that a sign's meaning (its interpretant) is perpetually lurking in possible future interpretations can offer basic educational insights. Stables has emphasized this "deferral of learning" repeatedly in his work: 
Meaning [and thus learning] is deferred, [...] that is, the meaning of every sign depends on its relations both spatially (to other signs) and temporally (to past experience and use). The point at which I learnt something is therefore not objectively measurable, nor, as my point in space-time is never yours, can my learning experience correspond exactly to yours. (Stables et al. 2018: 16)

On a basic level, stating that learning is deferred means that learning can be neither temporarily nor spatially pinpointed. If learning is neither locatable nor measurable in any singular event, then how can we constantly refer to its occurrence (and perhaps more strangely, its outcomes, or results) in policy, research, and teaching? It is precisely because learning is so often reduced to "normative judgements about desirable change" (Biesta 2016[2013]: 60) that learning is obfuscated and operationalized in the service of ideology. I wholeheartedly agree that unquestioningly presenting learning as something natural, "something we cannot not do, runs the risk of keeping people in their place" (Biesta 2016[2013]: 60). But doing away with the concept altogether is not an adequate solution, as Biesta seems to suggest. I argue that a wider and more encompassing conception of learning is needed.

But how do we reconcile this notion that learning is deferred, with the parallel experiential 'feeling of learning' that is implied in educere, and indeed the etymology of learning itself? ${ }^{11}$ The actual process of learning new knowledge and skills is often not experienced or expressed as an incremental "piling up", but takes the form of a winding process of discovery, a "drawing out" that the learner has been able to make sense of and re-cognize through further experience. Ling expresses this in the following 'quip' to his students undergoing 'Professional Teacher's Education':

Teaching is not 'rocket science.'

With all due respect to - and admiration for - the rocket scientists, it is actually a lot more complex than that.

What it $\underline{i s}$ is a way of relating to each other, and to oneself, perhaps even 'a way of being' that is full of depths, nuances, and mysteries, a way of being that in a certain sense begins, and ends, with an ongoing desire to learn about learning.

11 The Old English word 'leornian' (associated with the term, 'loeran' - 'to teach') has base roots in 'to follow or find the track' (cf. https://www.etymonline.com/word/learn?ref=etymonline_ crossreference); inviting reflection on this notion of educere and education as a 'leading out'. 
And so, if you can be receptive - and responsive - to those depths, nuances, and mysteries, if you can make learning about learning (which is to say, learning about the world, each other, and oneself, along with learning for each other and oneself) a central tenet of what guides us in being a teacher, then perhaps we can come to some understanding of what teaching is as a practice, what it has been, and what it can be.

-Michael's Quips, \#1 (.m ling, Fall 2018, PDP PLC \#9)

For Ling just like Ingold, there is an important experiential aspect of learning that comes prior to teaching that we need to take notice of: "Learning precedes teaching, insofar as it goes on without formal teaching, often enough, and, that effective teaching has to be shaped by an understanding of learning, first and foremost" (Ling, personal correspondence). Again, as Greene (2001[1972]) said, teaching is so difficult because it involves learning "to let learn". The pedagogical act of channeling learning implies that, although learning may be deferred (not fully locatable in space or time), learning still happens. Ingold (2013) arrived at this understanding that "learning precedes teaching" through reflecting on his early fieldwork with the Sami people of North Eastern Finland, when he was constantly told by his hosts to "know for yourself". He eventually concluded that these people were not simply being unhelpful, but rather fostering his own process of "learning to learn" (Ingold 2013); acquiring knowledge not through didactic explanation but through "a process of self-discovery". "To know things" he says, "you have to grow into them and let them grow in you, so that they become a part of who you are" (Ingold 2013: 1).

In this sense I have argued repeatedly that an understanding of learning can only be oriented around practices (I have written on this mostly in the context of music education). We can say with Stables (2016: 48), that the concept "[1] earning is empty without practices". This is also a reminder that we learn things for some purpose, even if this purpose is forever evolving and ultimately contingent upon further experiences.

Being a teacher means bringing something from the outside, that was not there to begin with. ${ }^{12}$ In my own teaching, what I bring to the table is usually a particular way of expressing varying modes of relation; an expressive indexicality; a 'look here', and a 'let's make sense of this together?' The only way I have been

12 In ecological accounts of educational dynamics, it can appear difficult to account for the role of the teacher as something more than just a facilitator of "good" learning environments (as in our accounts of e-learning above). Such an account of learning, while suitable to describe idealized constructivist scenarios, does little to escape the reification of learning that we discussed earlier, nor does it provide us a satisfactory account of "those great depths, nuances, and mysteries" that Ling expressed in his 'quip'. 
fortunate enough to develop some personal and pedagogical awareness of these modes of relating, is because I have engaged in varying forms of praxis myself (music, pedagogy, writing, reading). These practices have taught me how to dwell in relational correspondence, and more importantly to dwell in processes of becoming. I believe that it is only through an awareness of becoming, and not being, that we can cultivate the pedagogical sense of educere discussed.

As we will discuss in the following section, this is not ultimately a didactic force upon students, but the enacting of a ritualized process that can never be fully operationalized, as it changes from within and from without: through selfreferential processes of collective habit-taking that extend beyond the confines of the individual to incorporate the wider community and environment.

\section{Learning is continuous}

In previous research I have acknowledged more explicitly how this "quest for certainty" in describing and ensuring learning presents a serious challenge to dominant educational approaches. I have shown (Campbell 2017), how learning (like the life process itself) appears to be expressed in an anticipatory dynamic ${ }^{13}$ and is thus complex, and not complicated (as according to Nadin's notion of G-complexity, built on Gödel's famous incompleteness theorems). Anticipatory systems always preserve a certain degree of undecidability (vagueness). Through this criterion, scholars like Mihai Nadin have defined the difference between the living and the non-living as the difference between "undecidable complexity and decidable complication" (Nadin 2017: 154). ${ }^{14}$ The fact that learning is not reducible to formal reductions (that it transcends computation), ultimately points to another sense of deferral which we will be exploring in these next two sections.

Understanding learning as the growth of signification, or semiosis, means learning necessarily extends beyond the individual (and beyond reductionistdeterminist accounts) to incorporate the wider community, culture, and ecosystem.

13 "Within physics-based explanations, the current state of a system is determined by its past and is deterministically well defined, i.e., non-ambiguous. An anticipatory system is a system whose current state depends not only on previous states, and eventually its current states, but also upon possible future states" (Nadin 2010: 112).

14 According to Gödel's theorem: “[A] complex system cannot be fully and consistently described. All other systems (those that can be unequivocally specified) qualify either as simple or, at most, complicated. Within this view, complexity is not a matter of scale. Moreover, it does not accept degrees (the empty formula of "higher complexity" and the like). Since the living is characterized by complexity, it follows that any formal representation, including the modeling of the natural system, can be only a reduction" (Nadin 2014a: 78). 
This is learning that possesses an "evolutionary telos" according to Olteanu (in Stables et al 2018: 112):

In this conception, learning is therefore attributable to several agencies: to the individual, as it seeks its place in the environment, to neighbouring organisms, to its close groups, to its species, and to its relations to other species and to the entire phenomenon of evolution, both of its own species and of other species. As such, learning in the cultural sense is, at most, a sub-case of learning in the evolutionary sense, if not the same phenomenon altogether.

Learning, in this grand Peircean estimation, is not in any way unique to humans, but ultimately occurring on a continuum with all living organisms and indeed the wider universe. Olteanu (in Stables et al, 2018: 112) quotes Peirce in discussing this principle of continuity:

Specific human cultural learning and natural evolution are understood here as continuous, from the perspective of Peirce's notion of continuity. According to Peirce, constituting parts of a continuum are "individually indistinguishable in their very existence - that is, are distinguishable, and the parts distinguishable indefinitely, but yet not composed of individuals absolutely self-identical and distinct from the other". (CP 1.499) ${ }^{15}$

This is consistent with the understanding that learning transcends any reductionist process of fractionation (again it is G-complex, not complicated). It is deferred in the sense that it is never ending and reaches both forwards and backwards in time. Learning is therefore not something that can be broken down into constituent parts with the expectation that these parts can be consistently and completely described and used to construct formalized models that purport to explain the whole of the phenomenon.

Dewey, too, saw 'living and learning' as co-extensive. For him, both learning and the life process are both rooted in principles of growth and continuity. Living, he says:

[...] possesses continuity because it is an everlastingly renewed process of acting upon the environment and being acted upon by it [...] of relations between what

15 The guiding principle that "semiosis and the life-process are coextensive" has been the great contribution of Thomas Sebeok's (Sebeok 2001[1994], 2001; Sebeok, Danesi 2000) biosemiotic project. This central idea has been referred to as 'Sebeok's Thesis' by Kull, Emmeche and Hoffmeyer (2011: 2). This has encouraged some scholars and researchers in the emerging field of edusemiotics to say that semiosis and the learning process are co-extensive, along similar Peircean lines. 
is done and what is undergone [...] The world we have experienced becomes an integral part of the self that acts and is acted upon in further experience. In their physical occurrence, things and events experienced pass and are gone. But something of their meaning and value is retained as an integral part of the self. Through habits formed in intercourse with the world, we also in-habit the world. It becomes a home and the home is part of our every experience. (Dewey 2005[1934]: 108)

This experiential account of living leads Dewey to think of both learning and education through this broad criterion of habit: learning is the creation of habits that enable future habit-taking, and thus "the result of the educative process" can only be a capacity "for further education" (Dewey 2004[1916]: 68). ${ }^{16}$ As Dewey recognizes here, to be in-habit in this manner, is to be open to the evolving and changing environment, and to be out-of-habit is to be closed to it. To in-habit the world from such a deeply experiential place, is not to be in habit with a mindindependent reality "out there". No - it is to in-habit and dwell in a phenomenal world (or umwelt). Dwelling precedes re-cognition, and re-presentation. For Dewey (and to an extent his teacher Peirce) habit is "the principle of production" itself, "whereby a self that dwells in its own practices is recursively generated by them" (Ingold 2017: 22).

To inhabit an umwelt is to be receptive to the continual emergence of possibility and presence through habit. To come into presence, necessarily means coming into the presence of others (cf. Biesta 2016[2013]: 143). To study with others is thus to dwell in a collective and shared umwelten. To live, and more importantly, to live well, as a flourishing and adaptive organism, is to go on learning. ${ }^{17}$ Learning, then, from this perspective can be said to result in the creation of semiotic freedom that results from $d$ welling within habits of practice. ${ }^{18}$

16 Affifi (2014: 76) explains further: "For Dewey, growth occurs when possibilities open up for an organism, thereby "enhancing its ability to participate in its environment" (Gouinlock, 1972, p. 238). It is the process of developing habits that allow the organism to interact more spiritedly, responsively, and openly to arising circumstances. By contrast, a lack of growth limits possibilities of encounter, as the organism relies on preformed habits that stultify, ossify, and close it off to novelty [...] growth is predicated on habits that enable future habit-forming, whereas the restriction of growth occurs when existing habits monopolize the operational domain $[\ldots]$ ".

17 Following this Deweyan legacy, the emerging edusemiotic project has largely rallied behind the notion that we cannot separate education from life experience: "education is identical with the operation that is living a life that is fruitful and significant, the ultimate value which can be set up is just the value of living itself" (Dewey cited in Stables, Semetsky 2015: 84).

18 I have elaborated this pedagogy of dwelling recently in a forthcoming article called "Dwelling in music: The pedagogy of creative improvisation classes". 
But how far does this conception take us? What does this criterion of the growth of habits that enable future habit-taking really imply? Addiction can only be considered addiction when it closes possibilities and solidifies or closes our potential for future habit-taking. And furthermore, habits can only open to new habits in the context of particular practices. Because there is no pure equilibrium of habits that open possibilities (all possible openings require a closure of others), ${ }^{19}$ learning must always to some degree be a qualitative judgement of value, that is "sporadically enacted" through the practices that enact it. ${ }^{20}$ As Stables (2006) notes: if all living is expressed as semiotic-engagement between the organism and its environment; and, if all living necessarily involves change; and, if learning entails semiotic engagement that results in change; then, it must be concluded that "there is no clearly identified 'form of life' (to use Wittgenstein's term) that is learning" (Stables 2016: 48).

Fully recognizing this line of reasoning and all that it implies, I am arguing that there is, however, practical value to expanding our narrow use of the term 'learning' (at least in the anglophone world). This expansion of what learning can mean is performed in the interest of developing flexible telos (not outcomes) that can connect this process of learning to a broader ecological and evolutionary continuum. "Expanding our notions of learning" is a way to take control over the corruptions that the concept can suffer under the prevalent discourse of learnification. Furthermore, I argue that this "conceptual-exploding" has specific insight into the actual forms of life (teaching and learning) that educational institutions are said to channel, but do not determine.

Charls Pearson (2018: 412) notes that it is widely accepted by modern biology that "the essential attributes of life include functional autonomy, and selfreproduction". According to Pearson, biosemiotics adds an additional criterion, semiosis, or semiotic causation (which we shall be treating in more detail in Section 5 shortly): "These three attributes partake of a common trait, that of having an essential self-referential structure” (Pearson 2018: 412). The connecting link between a notion of living-as-semiosis and learning-as-semiosis is found in the

19 It is always dialectics of open and closed interpretations. For a fuller treatment of Eco's poetics of openness in the context of pedagogy, see Campbell 2018b.

20 Furthermore, we must tread carefully by making this alignment, questioning whether we are merely perpetuating the naturalization of learning that Biesta (2016[2013]: 68) warns us about, a slippery slope where: "(1) learning first becomes equated with living, (2) then almost necessarily becomes a lifelong process, which (3) next moves to the claim that any normal human being can learn, (4) then easily moves to the suggestion that therefore every normal human being should learn, so that (5) in the end, there must be something wrong with you if you do not want to learn and refuse the learner identify". 
fact that both rely on such self-referential structures. What mediate learner and environment, in an edusemiotic account, are signs: "The sign [...] acts as both confluence and influence, bringing together a set of habituated responses to similar although not merely identical situations, and thereby modifying future signification" (Stables 2018: 33).

This self-referentiality is central to Peirce's (triadic) semiotic, which rests upon what he called an extreme scholastic realism; where 'the possible' (firstness), 'the is' (secondness), and 'the would be' (thirdness) all possess 'real' causal efficiency and influence our actions in the unfolding present. The sporadic event of new learning can be conceptualized through the way regularity and habit give way to new habits and new chance occurrences (how thirdness gives way to firstness). Umberto Eco (2014: 514) explains this aspect of Peirce's categories:

The emergence of Firstnesses through their being opposed to one another (Secondness) starting from the regularity of the habit (Thirdness) for Peirce is an event (CP 6.200), i.e. a singularity, a point at which something occurs [...]. In this way the spontaneity of Firstness, whose irregular and singular nature Peirce underlines (CP 6.54) turns out to be nothing other than an infinitesimal deviation from the law and from the regularity on whose basis it is produced (CP 6.59).

Inchoative in this paragraph is an entire theory of pedagogical and artistic practice (see Campbell 2018c). It implies the importance of education: (1) being oriented around shared practices, and; (2) as being toward significant events that may induce an awareness of presence and possibility in learners. These significant events should be learner-aware and not merely learner-centred, ${ }^{21}$ for they ultimately extend beyond the learners themselves to embrace a wider continuum of community and environment.

I have argued before how a semiotic approach to pedagogy should ultimately be concerned with cultivating shared 'habits of feeling', a collective aesthetic responsiveness expressed in rituals of practice (see Campbell 2018a; 2018c) that aim to bring about significant experiences for students. For instance, many of the musical ensembles I teach orient around shared practices of music-making, not specific and determined music-learning outcomes. These shared practices

21 "To educate for significant events involves placing the emphasis on student activity though with clear and significant responsibilities for teachers. Adapted as a template for teachers, it would result in an approach that is not "learner centred" in terms of putting the primary emphasis on "what students bring to the topic", or in the student's assumed intelligence or cognitive capacity, but is certainly "learner aware" in terms of having to ensure that new activities "map onto" what has come before" (Stables in Stables, Semetsky 2015: 41). See also Stables (2018: 53-54). 
gradually become more and more habitualized through time: the ensemble continuously "learns" to approach these practices with care and preparation, by growing into the ritual and having it grow within them. This is a ritualized mode of communing with others that involves developing shared modes of attention and engagement. Again, this is a pedagogy aimed not at instilling knowledge or moulding learners to hold specific viewpoints (educare), but rather, a process of finding a path and following it; leading learners out of their familiar positions and habits. We will only be 'led out' together if we are engaged in practices together.

This requires, as educators, a sensitivity to what I have previously called the palimpsest nature of the categories. This is the principle that states that our experience is always necessarily triadic; how all three categories are always present, despite our level of awareness (see Campbell 2016; 2017; 2018c; 2018d). Thirdness - or the growth of possible interpretative responses and thus also the growth of action possibilities - occurs in perception to mediate between the processes of qualification (firstness) and sensory-impression (secondness) or, to put it more directly, to mediate the potential becoming actual in our ongoing experience (CP 1:429). As Torill Strand affirms, in this sense, “Thirdness is learning" (2013: 795). Thirdness is found in establishing new relationships to the world and expressed in the "emergent patterning" characteristic of life itself (Stables, Semetsky 2015: 63). This is, on a basic level, the capacity and potential for an organism to grow the meaningfulness of its umwelt. It is in this way that we can understand learning in the abovementioned Deweyan sense as the creation of habits that enable future habit-taking - habits that enable the learner to go on learning within the context of specific practices, and in this sense also "the formation of habits that will engender a [future] receptiveness to novelty" (Campbell 2017: 17). ${ }^{22}$ Aligning learning with the growth of semiotic possibilities implies the necessity of life-long learning, but not in the narrow instrumentalist sense we discussed before. Again, this is the basic premise that learning is continuous, that " $t$ ] he more an organism learns the more it still has to learn: education means more education and becoming more developed signs" (Semetsky in Stables, Semetsky 2015: 81).

Peirce sees semiosis as bridging any distinctions of mind and matter, and thus connects what he considers "the irreducibly triadic nature of the universe" to the problem of the origin of life itself:

[T] he problem of how genuine triadic relationships first arose in the world is a better, because more definite, formulation of the problem of how life first came about; and no explanation has ever been offered except that of pure chance, which

22 For a fuller treatment of this 'pedagogy of novelty', see Campbell 2016, and Nöth's discussion of my ideas in Stables et al. 2018: 80-81. 
we must suspect to be no explanation, owing to the suspicion that pure chance [firstness] may itself be a vital phenomenon. (CP 6.322)

For Peirce, it is futile and fallacious to think of mind and matter as categorically distinct. Because we know that mind must have emerged from matter in some capacity, the relation can only be continuous (cf. Deacon 2011). Living organisms in-habit their umwelt, by forming varying modes of relationship, 'scaffolding' the conditions for their ongoing adaptation.

This perspective is in line with the biosemiotic project, which has been said to examine "the processes and consequences of habit-making via sign activities in living beings" (Affifi 2014: 73). Biosemiotics rests upon the hypothesis (expressed by the above Peircean quote) that "there is a semiotic core seeding the emergence of biological systems, from cells to ecologies" (Affifi 2014: 74). From here we can understand the biosemiotic and edusemiotic project as shared, as both orientations concern themselves with the "processes and consequences" of semiotic habitmaking; the emergence of genuine triadic relationships, that enable growth to occur. As I've discussed elsewhere, this is essentially how an organism's "action in the world effects (through a constantly evolving anticipatory dynamic) how the organism will continue to act, and how through these actions the environment itself changes (by incorporating the actions of the organism into it and breeding semiosic plurality)" (Campbell 2017: 11).

Throughout his life, Peirce gradually expanded and grew his concept of habit: first understanding the generalizing tendency as an essential law of mind (see CP $6.21,1891$ ); and eventually extending this notion of generalization to incorporate not only the life of signs (CP 2.222, "a symbol is a living thing"), but more broadly, manifestations of "life in general, in the evolution, development and growth of organisms and their associations" (Fernández in print $a$ ). In his late semiotic philosophy, Peirce began to fully extend his concept of habit as the universal generalizing tendency itself, and it found a central place in his evolutionary cosmology. ${ }^{23}$

23 According to Charls Pearson (2018: 395), expounding the legacy of his friend Eliseo Fernández in an overview memorial essay: "Peirce's habit grew to become a centerpiece, not only of his mature semeiotic, but also of his prescient evolutionary cosmology". According to Fernández, this consists in a generalizing of the concept of habit itself as being synonymous with the modern scientific notion of tendency. Eliseo's "boldest move" says Pearson, consists in reversing the traditional hierarchy of substance - tendency, by arguing that from a fully semiotic perspective, tendencies are more basic than substances. As we've already alluded to, at this level of abstraction Peirce's notion of Habit becomes synonymous with "a tendency to enact the same tendency every time the same precipitating circumstances are enacted. Therefore [...] habits are simply higher-order tendencies that repeatedly release lower-order tendencies 
I will now explore how this broad criterion of Peircean habit-taking as a "cosmic phenomenon" may allow us a viewpoint from which to consider first-order (physical) causation as continuous with second-order (final, or telic) causation. This interplay of matter and mind has been explored in biosemiotics research through the late work of the brilliant Argentine-American librarian/scholar Eliseo Fernández (from approx. 2008 till his death in 2017), ${ }^{24}$ most directly through his seminal notion of semiotic causation. I will try to show how, through such considerations, it is possible to view the environment, and the universe itself, as always evolving, growing, and, in a certain extension of the term, learning.

\section{Learning as semiotic evolution}

Learning is part of living. As Olteanu (in Stables et al. 2018: 105) says, "[l]earning is a vital symptom: we learn as long as we are alive, and we are alive as long as we learn. This mutuality of learning and living is meant to be understood in both existential and biological senses". Both learning and living (understood through the criterion of semiosis) can be said to be teleological processes. They are processes oriented towards possible or "virtual" states of being. Peirce's "grand vision" (see Footnote 25) implies that the teleologies displayed by organisms "have their evolutionary roots in final causation, which is present at all levels of nature." (Fernández in print b). To explain how this continuity occurs, Fernández presents us with his seminal theory of semiotic causation (see Fernández 2012, 2017). Pearson (2018: 399-400) summarizes this theory cogently in the above-mentioned In Memorium article (see Footnote 25):

Biological causation may turn out to be a generalization of classical physical causation, in the sense that ordinary causation may then appear as a special,

into action whenever similar circumstances are reenacted." This is what Fernández claims is Peirce's "mature evolutionary vision" (Pearson 2018: 396). Although it will not be possible to fully elaborate the details of Fernández's biosemiotic approach to the philosophy of science, I believe that realizing this mature vision allows us a vantage point to consider seriously a fully pansemiotic perspective. The approach to habit as tendency is very much in line with the edusemiotic project; both reverse the traditional hierarchy of substances as the stable furniture of the world to recognize that "relation is ontologically basic" (Noddings 2010: 390).

24 This ground-breaking work has been presented in a series of eleven papers (seven published and four soon to be published), featured in Chinese Semiotic Studies' 'Peirce Section' (previously created and edited by Pearson, and more recently edited by myself following Pearson's retirement in late 2017). See Pearson (2018) for a summary and treatment of this series of articles. 
limit case of the forms of causation manifest at the level of living systems. This approach treats semiosis as a form of second-order causation; it causes changes, amplifications, or inhibitions upon ordinary processes of physical (first-order) causation. It does not act directly by a discharge of energy, as in physical causation. Instead, it changes the course of events by modifying the constraints that in all physical phenomena modulate the flow of energy towards its final dissipation. Peirce suggested that physical causes act by channeling the trending of energy towards its dissipation; a top-down explanation. Fernández suggests a heuristic approach to causal top-down explanations based on the interplay of three factors: 1) a source of free energy moving spontaneously towards its complete dissipation; 2) structures that resist, redirect, and channel the flow of energy in various ways (constraints); and 3) a tendency to reproduce similar effects every time similar energy flows and constraints are reproduced (habit). These three factors, spontaneity, constraints, and habit are instances of the Peircean categories of firstness, secondness, and thirdness. Based on this triadic conception of physical causation, he further proposes to treat semiosis as a form of second-order causation [...]: semiosis causes changes in the causal action itself. It alters the way that energy is channeled by acting on the habits embodied in the constraints that guide the flow of energy towards equilibrium.

As much edusemiotic research is concerned with understanding the dynamics of learning as semiosis it is important to consider how semiosis is continuous with, but still distinguishable from, first-order, physical causation: distinguishable, yes, "yet not composed of individuals absolutely self-identical and distinct from the other" (CP 1.499). This has been discussed in edusemiotics through the principle of suprasubjective relation (or PSR). ${ }^{25}$ The very principle of semiotic causation implies suprasubjectivity by nature of being a form of second order causation, dependent upon ordinary first-order causation (it is, as Pearson and Fernández note, triadic). More directly, this is to say that 'signs' are not divorced from the world, but dependent on the 'things' that furnish their existence. As Augustine famously opens De Doctrina Christiana: "learning concerns either things or signs, but it is through signs that we learn what things are" ([397AD], Book 1, Line 2). In this form of scholastic realism, historically culminating with Poinsot's Tractatis de Signis (see Poinsot 1985[1632]), there is a reversal of the modern convention of defining subject-object relations antithetically. Here, objects are only objects if they are "objects within our awareness". That is, if they become signs, signifying something (some meaning) within our phenomenal world or umwelt. What is subjective is that which "is what it is regardless of what we know of it", thus it is

25 In the context of ecological edusemiotics, see Olteanu in Stables et al. 2018 and Campbell 2018d. This notion of suprasubjectivity has been most developed in modern times through the work of John Deely (cf. Deely 1990). 
of the order of mind-independent reality (or ens reale, a hypothetical "operational environment", distinct from our "cognized environment", cf. D’Aquili et al.: 1979). ${ }^{26}$

This philosophical location of learning in the growth of signs, which are themselves dependent upon physical forms of causation, has major implications. Learning in this estimation is something that, despite its immateriality - its absence -, still impacts and influences the present unfolding. Responding and interpreting signs means that the organism is forming a relation to its environment; that it means something to it. Kull (2009: 82) similarly explains the Peircean triadic sign model through reference to anticipation and 'absential phenomena':

The sign vehicle, or representamen (or sign, sensu stricto), stands for an object. This is the relation that is created by semiosis. The object, thus, has an interesting duality - it is both there and is not there - because it is both connected and anticipated. The relation of standing for is possible owing to the absence of what is referred to (the object) and, concurrently, there cannot be semiosis without the existence of a reference (an object) [...]. Semiosis is what makes anything plural.

We can say that these immaterial "supra-subjective" relations, that make physical things plural, are the proper object of educational studies. Although possessing subjective/material fundaments (of the order of Secondness), these relations transcend "over and above" such spatial temporal terminus, reaching both forwards and backwards in time. This provides another way of understanding why 'learning' is always absent in our accounts of it: we can say, with Deacon (2011: 2-3), "there is something not there, there.". ${ }^{27}$ From here we can better make sense of the alignment that learning is co-extensive with living, as both are expressed in processes by which an organism makes and finds meaning in its environment. With Augustine, learning is a term we apply to the process by which an organism turns the 'things'

26 Deely (1990: 100) describes the revised (at least by the moderns) notion of 'objective reality' that semiotic causation illuminates, explaining why: "[a]ny attempt to restrict semiosis to cognition falls short at the level of theory for the reason that nature and culture mutually penetrate one another in the constitution of experience, so the objects of experience also reveal themselves more suited to some significations than to others in any given context or inquiry. The objective sphere reveals itself as neither closed nor closable upon itself absolutely [...]. The full semiosis of experience, thus is never merely actual, but is suffused at every moment with elements and factors passing in and out of varying degrees of actuality and consciousness through the virtualities that remain in their own right semiosic [...]".

27 "Each of these sorts of phenomena - a function, reference, purpose, or value - is in some way incomplete. There is something not-there there. Without this "something" missing, they would just be plain and simple physical objects or events, lacking these otherwise curious attributes. Longing, desire, passion, appetite, mourning, loss, aspiration - all are based on an analogous intrinsic incompleteness, an integral without-ness". 
of its environment into 'signs', signifying something beyond themselves, enabling the growth of meaning. It is through such a growth of meaning that the organism can adapt to and channel semiotic complexity in its umwelt, in the context of particular habits (practices) of engagement.

This notion of semiotic causation as continuous across mind-matter distinctions shows us again that it is impossible to hierarchize or dichotomize organisms based on their presumed complexity: as each umwelt, no matter how seemingly deficient when compared to other "standards of life", is full and complete in itself. No umwelt is lacking. The implication that "learning is suprasubjective" (PSR) implies that learning is not fully explained through cultural explanations cut off from biology or the environment. With this logic, neither can there be a strict hierarchy of intelligences at all, based on the all too common operational pedagogical belief that 'the child = incomplete adult". Education is not about ensuring what a child ought to become; it is about recognizing the sporadic event of becoming itself, as it emerges within our shared experience. Learning is ecological, a result of inhabiting an umwelt, and because of this it occurs on a continuum.

To in-habit an umwelt implies responsibility towards it. To learn then, is to have some changing sense of what has come before (memory system, history) and this is, according to insights in biosemiotics, expressed in processes of semiotic scaffolding. ${ }^{28}$ Scaffolding is the inevitable effect of an organism being in habit with its environment. Put directly, this is to say that the organism projects its own embodied morphology onto the environment and, through a self-referential process of action and response, both changes and is changed by it: "It becomes a home and the home is part of our every experience". ${ }^{29}$ As semiotic causation is dependent upon an interaction with efficient causation it will ultimately always

28 "The network of semiotic interactions by which individual cells, organisms, populations, or ecological units are controlling their activities can thus be seen as scaffolding devices assuring that an organism's activities become tuned to that organism's needs" (Hoffmeyer 2008a: 154). This concept has been developed throughout Hoffmeyer's biosemiotic project (see Hoffmeyer 2015), adopted and expanded from earlier educational research - see Olteanu and Campbell 2018: 252-254 for discussion on this. Interestingly, Fernández (in print b) considered semiotic scaffolding as a corollary conception to his own theory of semiotic causation.

29 I have explored this process in greater depth elsewhere (Campbell 2018c), through a revising of Eco's notion of primary iconism, understood as the terminus a quo of perceptual learning. All learning begins from such a place of "primary iconism", which is merely the presupposition to correspond to an object, prior to any encounter with it (a firstness). This is consistent with the view, expressed by Sebeok and Danesi (2000: 199) "that all modelling is initially guided by sensory processes", also called the sense-implication hypothesis. See also Campbell 2018d for more on how Modelling Systems Theory can be adopted in educational contexts, and the related Iconicity Hypothesis. 
impact upon the world materially; by orienting and channeling energy differently. As Fernández (in press b) says in an introspective comment, "The telos of semiosis is the creation of an interpretant, and this is achieved by the transmission of a form". ${ }^{30}$ From here, we may fully comprehend the significance of Olteanu's (in Stables et al. 2018: 106) argument that learning can be understood as the "telos of life". Learning organisms are more open to the growth of signification in their umwelt; better able to 'scaffold' their environment, so that their actions in the world become more tuned to its needs. I believe, this notion of semiotic causation is conceptually powerful as it allows us an opening from which to consider a fully pansemiotic hypothesis where one can analogously come to think of the universe as both living and adapting, as Peirce in fact did.

Although such conjectures about semiosis as a universal and cosmic force may be ultimately speculative, for the practical purposes of education dividing this line is not conceptually useful. Stables has advocated for just such a fully non-dualist perspective on the philosophy of education; one that recognizes that pragmatically there is no point in adopting anything less than a pansemiotic perspective. ${ }^{31} \mathrm{~A}$ notion of habit-taking is essential to this expanded conceptualization:

The way we change through modulating habitual responses in new contexts is a complex version of what happens in simpler contexts. When a ball is repeatedly thrown against a wall, both the ball and the wall gradually change, although the latter generally more slowly than the former. Scaled up to the complexity of a human being (noting that we are bound to see ourselves as complex), the same principle can apply. We do not need separate operational categories for human action, such as reason or mind, for this to hold. (Stables et al. 2018: 46)

Although semiotic causation is something characteristic of organisms, with their ability to re-channel and re-interpret their umwelt for their own evolving needs, we must also extend our notion of learning beyond the organismic level. From this pansemiotic perspective, the process of evolution is not simply a continuous growth in complexity. Another way to explain this: the simplest organisms (the monocells, for example) are not actually simple, but rather a single component of

30 I think we may read 'form' in this usage as 'model'; noting also that, according to Sebeok (2001: 23), the English word that most approximates the meaning of the German term 'Umwelt' is 'model'.

31 But is there any use to thinking of Peirce's notion of semiosis, or semiotic causation, as what separates living beings from non-living things? From a fully Peircean perspective we should not divide this line, in order to preserve the principle of continuity. Although a scientist like Nadin will do so with the more specific purpose of researching and experimenting on anticipatory systems (see Campbell 2017: 12-13). This is because, for Nadin semiotics remains fully a modelling theory, and not an attribute of nature in its own right. 
extensive intercellular structures designed to perform complex semiotic operations. Research in endosemiotics has gradually confirmed this: plants not only communicate, they communicate on an intersubjective level far more complex than many have imagined possible. Again, all life is complex (G-complex, as for Nadin), only commutation is complicated. In this understanding, more individualized organisms (non-plant and fungi lifeforms) represent more closely centralized concentrations of semiotic causation. They simply represent different modes and expressions of semiosis and not an increase in complexity. Olteanu (Stables et al. 2018: 105) explains further: "[...] on Peirce's account, signification did not evolve from simple to complex, but that which is biologically simple presents complex semiotic structures, to which natural evolution itself adapted to recognise and use". From this reasoning, we can recognize the process of evolution itself on semiotic grounds - where the universe can be understood as a never-ending process of inquiry and interpretation. In this manner, Peirce viewed the entire universe as a kind of evolutionary argument-structure. This understanding of "[s]emiotic evolution is then taken to rest upon the ongoing differentiation, articulation and subdivision of simple Argument structure, facilitating the growth of semiotic freedom and cognitive capabilities over the course of evolution" (Stjernfelt 2014: 9). A growth in semiotic freedom is inevitably expressed in the capacity of an organism to model its environment in its own species-specific manner; to learn (to "find the track") within its umwelt.

Organisms gradually evolve to use and recognize these signs through their life-span, and this type of competence ${ }^{32}$ is passed down bio-genetically as well as through social forms of learning and teaching. Some organisms, in order to meet semiotic complexity in their environments, may evolve to convert exosemiotic resources into endosemiotic ones. This refers to the evolutionary process by which complex intercellular and multi-species networks are progressively made interior, and eventually replaced with centralized nervous systems. This creates in turn more strongly individualized lifeforms that, as Olteanu points out, also have the honour of dying alone. Seeing learning as continuous with the life and evolutionary process allows us to conceptualize learning-as-semiosis radiating beyond the individual organism. This is an understanding that tries to make sense of this phenomenon on a much grander evolutionary continuum. Recognizing learning across a continuum of related interconnected processes is to recognize with Ling (personal correspondence), that "we each are elements, we each are 'learning processes' in a larger 'cosmic' process of learning (the universe coming to understand itself)".

32 See Campbell 2018d for a treatment of this notion of 'competence' in terms of Modelling Systems Theory (Sebeok, Danesi 2000). 


\section{Conclusions}

We have now explored this concept of learning from various levels and perspectives: at the level of everyday educational discourses, exploring the ways the concept is co-opted and misused; its relation to different conceptions of education (educere-educare); its phenomenology or experiential basis; and finally, as a form of adaptation and evolution. Why then, have I insisted on using this concept of learning in orienting my own pedagogy and research?

Well, on a personal level, because it was only through treating the way I learned seriously as a young person (learning to learn) that I was able to overcome my own struggles with dyslexia; because this notion served a pragmatic function, enabling me to adjust and adapt my own action and perception. And it is on this point that I differ from Biesta, while at the same time, hearing seriously his plea for considering the politics and power that is spread through learnification.

My thinking, following this gradual telescoping of the concept, is that we must as educationalists and semioticians run towards learning as a "sensible" and meaningful concept - not away from it. This in fact may be the only way we can effectively resist naturalizing the concept, in both theory and practice. Realizing learning as something emergent and sporadic, allows us to resist turning learning into an accountability tool that can be used towards ideological ends. It also explains how learning is something felt, as our concepts themselves map a changing field of experience. Viewing learning through the criterion of semiosis means that learning is continuous in the entire biological realm and does not in any way begin with human beings, or what is sometimes called cultural learning. All living is expressed in semiotic-engagement and living necessarily involves continual adaptation and meaning-making, not just human meaning-making. From here we can understand the persistent insight from the anthropology of education, that social groups scaffold environments in which learning can happen in order to both sustain social-cohesion (educare) and ensure their ongoing adaptive capacity to uncertainty (educere). From a semiotic perspective, this is what schools and all educational institutions (no matter how "informal") are pragmatically for. Educational institutions are understood as instances of exaptation, that evolved naturally to channel learning more efficiently for specific social groups. ${ }^{33}$

33 Education can thus be understood as "an institutional means to influence the direction of ongoing semiotic engagement by learners with the world they inhabit. The role of education, broadly defined, therefore includes the preparation of learners to respond effectively, adaptively, and in collaboration or competition with others, to uncertainty, surprise and novelty" (Gough, Stables 2012: 370; my italics, C. C.). 
As we have already mentioned, teaching and learning, can only be sporadic; they emerge in the specificity of a moment and present themselves to reflection as an initial presupposition of what is educationally desirable (Biesta 2016[2013]: 89). The teacher cannot ensure that their teaching will be received or understood "teaching is always the giving of a gift that one doesn't possess" (Biesta 2016[2013]: 52) - and because of this we must practice a "pedagogy of the event" (Biesta 2016[2013]: 139) - because it is only in emergent and sporadic events that break through the walls of routine consciousness where novelty can find the possibility of being re-cognized and granted meaning and significance. We cannot, as teachers, afford to control or pin down these events; we can only practise our joint capacity for response and attention, and it is in this sense that educere is always about 'leading out together' and that a teacher in order to teach at all must also be able and ready to learn. Both teaching and learning alike, then, depend on a collective ability to develop "habits of feeling" (Campbell 2018a) that will enable our openness to changing and novel events. This is the power in the designation 'learner' - not by subscribing or forcing a learner identity (no different than assuming that the role of education is in ensuring productive citizens), but by reminding us implicitly of the essential complementarity of teacher and learner. That we can only learn together; that education implies plurality and togethering.

\section{References}

Augustine of Hippo 2009[A.D. 397-426]. On Christian Doctrine. (Shaw, James F., trans.) Mineola: Courier Corporation.

Affifi, Ramsey 2014. Biological pedagogy as concern for semiotic growth. Biosemiotics 7(1): 73-88.

Bass, Randall V.; Good, J. W. 2004. Educare and educere: Is a balance possible in the educational system? The Educational Forum 68(2): 161-168.

Berardi, Franco "Bifo" 2012. The Uprising: On Poetry and Finance (Intervention Series 14). Los Angeles: Semiotext(e).

Biesta, Gert 2013. Giving teaching back to education: Responding to the disappearance of the teacher. Phenomenology \& Practice 6(2): 35-49.

- 2016 [2013]. The Beautiful Risk of Education. Abingdon: Routledge.

Campbell, Cary 2016. Indexical ways of knowing: An inquiry into the indexical sign and how to educate for novelty. Philosophical Inquiry in Education 24(1): 15-36.

- 2017. Learning that reflects the living: Aligning anticipation and edusemiotics. Public Journal of Semiotics 8(1): 1-25.

- 2018a. Toward a pedagogy of firstness: Aesthetic education as Firstness experience. Chinese Semiotic Studies 14(1): 71-102.

- 2018b. Educating openness: Umberto Eco's poetics of openness as a pedagogical value. Signs and Society 6(2): 305-331. 
- 2018c. In search of our beginnings: Locating 'firstness' in arts education in the service of advocacy. International Journal of Education \& the Arts 19(13): 1-36.

- 2018d. Educating semiosis: Foundational concepts for an ecological edusemiotic. Studies in Philosophy and Education, 1-27.

CP = Peirce, Charles Sanders. The Collected Papers of Charles Sanders Peirce. (Hartshorne, Charles; Weiss, Paul, eds. 1931-1935; Burks, Arthur W., ed. 1958. ) Cambridge: Belknap. [In-text references are to CP, followed by volume and paragraph numbers.]

D’Aquili, Eugene G.; Laughlin, Charles D.; McManus, John 1979. The Spectrum of Ritual: A Biogenetic Structural Analysis. New York: Columbia University Press.

Deacon, Terrence 2011. Incomplete Nature: How Mind Emerged from Matter. New York: W. W. Norton \& Company.

Deely, John 1990. Basics of Semiotics. Indianapolis: Indiana University Press.

Dewey, John 2004[1916]. Democracy and Education. Mineola: Dover Publications.

- 2005[1934]. Art as Experience. New York: Penguin.

Eco, Umberto 2014. From the Tree to the Labyrinth. Cambridge: Harvard University Press.

Ergül, Hakan; Ingold, Tim2017. On anthropology, education and university: An interview with Tim Ingold. Moment Journal 4(1): 7-13.

Fernández, Eliseo 2012. Semiosis and phase transitions in biology: A Peircean view. Chinese Semiotic Studies 8(1): 164-177.

- 2017. Semiosis and emergence: The place of biosemiotics in an evolutionary conception of nature. Chinese Semiotic Studies 13(4): 399-409.

- In print a. Habit and generalization. Chinese Semiotic Studies.

- In print b. From tendencies to purposes: Peirce between Aristotle and Kant. Chinese Semiotic Studies.

Greene, Maxine 2001[1972]. Reflections on teaching. In: Richardson, Virginia (ed.), The Handbook of Research on Teaching. (4th ed.) AERA Publications: Washington.

Hoffmeyer, Jesper 2008a. Semiotic scaffolding of living systems. In: Barbieri, Marcello (ed.), Introduction to Biosemiotics: The New Biological Synthesis. Dordrecht: Springer, 149-166.

- 2008b. The semiotic niche. Journal of Mediterranean Ecology 9: 5-30.

- 2015. Introduction: Semiotic scaffolding. Biosemiotics 8: 153-158.

Ingold, Tim 2000. The Perception of the Environment: Essays on Livelihood, Dwelling and Skill. Abingdon: Routledge.

- 2013. Making: Anthropology, Archaeology, Art and Architecture. Abingdon: Routledge.

- 2017. Anthropology and/as Education. Abingdon: Routledge.

Kull, Kalevi 2009. Biosemiotics: To know, what life knows. Cybernetics \& Human Knowing 16(3-1): 81-88.

Kull, Kalevi; Emmeche, Klaus; Hoffmeyer, Jesper 2011. Why biosemiotics? An introduction to our view on the biology of life itself. In: Emmeche, Claus; Kull, Kalevi (eds.), Towards a Semiotic Biology: Life is the Action of Signs. London: Imperial College Press, 1-21.

Magnus, Riin; Tønnessen, Morten 2010. The bio-translator - interview with professor in biosemiotics Kalevi Kull. Hortus Semioticus 6: 77-103.

Masschelein, Jan 2010. E-ducating the gaze: The idea of a poor pedagogy. Ethics and Education 5(1): 43-53.

Nadin, Mihai 2010. Anticipation and the artificial: Aesthetics, ethics, and synthetic life. AI \& Society 25(1): 103-118. 
- 2014a. G-complexity, quantum computation and anticipatory processes. Computer Communication \& Collaboration 2(1): 16-34.

- 2014b. Semiotics is fundamental science. In: Jennex, Murray E. (ed.), Knowledge Discovery, Transfer, and Management in the Information Age. Hershey: Information Science Reference, $76-125$.

- 2017. Anticipation and the brain. In: Nadin, Mihai (ed.), Anticipation and Medicine. New York: Springer, 147-175.

Noddings, Nel 2010. Moral education in an age of globalization. Educational Philosophy and Theory 42(4): 390-396.

Olteanu, Alin 2016. Review of edusemiotics. Social Semiotics 26(5): 582-586.

Olteanu, Alin; Campbell, Cary 2018. A short introduction to edusemiotics. Chinese Semiotic Studies 14(2): 245-260.

Pearson, Charls 2018. In memoriam: Eliseo Fernández: semiotics' dear friend, with deepest sympathy. Chinese Semiotic Studies 14(4): 393-418.

Poinsot, John 1985[1632]. Tractatus de Signis: The Semiotic of John Poinsot. (Deely, John; Powell, Ralph Austin, eds., comm.) Berkeley: University of California Press.

Rancière, Jacques 1999. Disagreement: Politics and Philosophy. Minneapolis: University of Minnesota Press.

Sebeok, Thomas A. 2001[1994]. Signs: An Introduction to Semiotics. (2nd ed.) Toronto: University of Toronto Press.

- 2001. Global Semiotics. Bloomington: Indiana University Press.

Sebeok, Thomas; Danesi, Marcel 2000. The Forms of Meaning: Modeling Systems Theory and Semiotic Analysis. Berlin: Walter de Gruyter.

Semetsky, Inna; Campbell, Cary 2018. Semiotics and/as education: An interview with Inna Semetsky. Chinese Semiotic Studies 14(1): 121-128.

Stables, Andrew 2006. Sign(al)s: Living and learning as semiotic engagement. Journal of Curriculum Studies 38(4): 373-387.

- 2012. Be(com)ing human: Semiosis and the Myth of Reason. Rotterdam, Boston, Taipei: Sense Publishers.

- 2016. The end(s) of learning and the role of instruction: Shaping the debate. In: Witt, Paul (ed.), Handbooks of Communication Science. Vol. 16: Communication and Learning. Berlin: Mouton de Gruyter, 43-65.

Stables, Andrew; Semetsky, Inna 2015. Edusemiotics: Semiotic Philosophy as Educational Foundation. London: Routledge.

Stables, Andrew; Nöth, Winfrid; Olteanu, Alin; Pesce, Sébastien; Pikkarainen, Eetu 2018. Semiotic Theory of Learning: New Perspectives in the Philosophy of Education. Abingdon: Routledge.

Stjernfelt, Frederik 2014. Natural Propositions: The Actuality of Peirce's Doctrine of Dicisigns. Boston: Docent Press.

Wattchow, Brian; Prins, Alex 2018. Learning a landscape: Enskilment, pedagogy and a sense of place. In: Howard, Peter; Thompson, Ian; Waterton, Emma (eds.), The Routledge Companion to Landscape Studies. Abingdon: Routledge, 134-144. 


\section{Возвращение 'обучения' в образование: В сторону экологической концепции учебы и обучения}

В статье описывается обучение как адаптивный семиотический рост. Обучение рассматривается в широком экологическом и эволюционном континууме как форма адаптации к окружающей среде. Рассматривание обучения с помощью критерия значения (semiosis) означает, что обучение протекает непрерывно во всей биосфере. Жизненные и учебные процессы выражаются в формах семиотического вовлечения и содержат непрерывную адаптацию и создание новых значений. Таким образом, обучение нельзя считать присущим только человеку, оно является экологическим, прежде чем становится явлением культуры. Исходя из этого можно образовательные учреждения представить как формы экзаптации, которые оформились в природе. Включение обучения в экологический континуум означает, что обучение не может быть раз и навсегда быть локализовано в теории и практике образования. Скорее всего обучение является спорадическим, оно выявляется в специфике событий и его нужно выделять в рамках обучающих практик. Понимание обучения в качестве чегото, что исполняется в образовательной встрече, а не строго установленным правилами позволяет нам сопротивляться превращению обучения в инструмент, который может легко использоваться в идеологических целях.

\section{'Õppimise' tagasitoomine haridusse: õppimise ja õpetamise ökoloogilise kontseptsiooni suunas}

Artiklis kirjeldatakse arusaama õppimisest kui adaptiivsest semiootilisest kasvamisest. Kooskõlas erinumbri teemaga lähenetakse õppimisele avara ökoloogilise ja evolutsioonilise kontiinumi kaudu, mis kõige üldisemalt väljendub keskkonnaga adapteerumise mõne vormina. Õppimise vaatlemisel tähenduse (semioosi) kaudu osutub, et õppimine toimub katkestamatult üle kogu bioloogilise valla. Nii eluprotsesse kui ka õppimisprotsesse esitatakse semiootilise hõivatuse vormidena ning nende juurde kuulub kestev adapteerumine ja tähendusloome. Seega ei või õppimist pidada inimestele ainuomaseks. Õppimine on palju avaramalt ökoloogiline, enne kui saab "kultuuriliseks". Sellest lähtudes võime haridusasutusi vaadelda kui eksaptatsiooni vorme, mis kujunesid välja looduslikult, et õppimist tõhusamalt suunata. Õppimine ökoloogilises kontiinumis tähendab, et õppimist ei saa haridusteaduses ega -praktikas hõlpsasti "lokaliseerida" ega paika naelutada. Pigem on õppimine sporaadiline identiteet; see kerkib esile sündmuste spetsiifilisuses ning seda tuleb eritleda nende praktikate raames, mis seda täide viivad. Õppimise mõistmine millenagi, mida hariduskohtumises tekkivana täide viiakse, ja mitte millenagi, mida on võimalik määratleda ja rakendada, võimaldab meil vastu seista õppimise muutmisele vastutamistööriistaks, mis on hõlpsasti kasutatav ideoloogilistel eesmärkidel. 